\title{
The Concept of Regulating Forest Management in a Region Subject to High Environmental Pressure
}

\author{
Tomasz Borecki ${ }^{1}$, Łukasz Łopiński ${ }^{2}$, Wojciech Kędziora ${ }^{1, *} \mathbb{1}$, Michał Orzechowski ${ }^{1}$, \\ Roman Wójcik $^{1}$ and Edward Stępień ${ }^{1}$ \\ 1 Department of Forest Management Planning, Faculty of Forestry, Warsaw University of Life Sciences - \\ SGGW, 02-776 Warszawa, Nowoursynowska 159, Poland; tomasz.borecki@wl.sggw.pl (T.B.); \\ michal.orzechowski@wl.sggw.pl (M.O.); roman.wojcik@wl.sggw.pl (R.W.); \\ edward.stepien@wl.sggw.pl (E.S.) \\ 2 Łochów Forest District, 07-130 Łochów, Wyszkowska 28, Poland; lukasz.lopinski@warszawa.lasy.gov.pl \\ * Correspondence: wojciech.kedziora@wl.sggw.pl; Tel.: +48-22-59-38-204
}

Received: 23 July 2018; Accepted: 31 August 2018; Published: 1 September 2018

\begin{abstract}
In modern forestry, the complexity of the planning process is increasing, specifically in the context of the sustainable use of forest resources and its adaptation to climate changes. This article presents the concept of forest use regulation promoting the sustainable forestry development in forest management planning. A method for defining a synthetic criterion of assessing important features of stand structure was proposed, which would enable the classification of stands in terms of needs and the urgency of their transformation (reconstruction) or suitability for longer standing. As a result, such a concept may ensure the preservation of the relative uniformity of logging use and the improvement of age structure as well as an increase of natural values of the forest, regardless of a stand's age. The concept was tested on a large forest complex (over 0.5 million hectares) subjected to intense environmental pressure (Silesian Region in Poland). We prepared long-term individualistic development forecasts, separately for area and volume. Based on this, we followed the cutting uniformity principle in the analysed time period by calculating a long-term average of cutting allowance. It was determined by averaging the projected usage size in moving window and eventually was adopted as the cutting upper limit in the whole analysed period. The proposed size of cuts in each period resulted from the relation between the average value and the forecast. Three sets of stands of the differentiated urgency of interventions were distinguished: I-well-stocked and stable stands (no need of intervention) - $55 \%$ of stands area, II - acceptable stands (not urgent intervention needed) $-35 \%$ and III-poor stands (urgent intervention needed) $-10 \%$. This concept joins top-down and bottom-up approach of cutting uniformity that focuses stand's status instead of its age or dimensions.
\end{abstract}

Keywords: forest management planning; stand conversion; sustainable development of forests; multifunctional management; sustainable development goals

\section{Introduction}

Modern forestry in Europe is linked to an increasing number of economic operators and social groups interested in the availability of specific forest benefits. Representatives of industry, agriculture, urbanisation, traffic, water management, health care, nature protection, hunting, tourism and recreation, among others, are usually guided by their own opinions as to the scope and intensity of forest use and its resources [1,2]. This makes demands competitive and usually puts forestry in a conflicting position when it comes to defining tasks and choosing the means to implement them. Objective assessment of possibilities and economic consequences is also hampered. 
Estimating the value of complex forest services is a complex task and it needs resilience thinking in planning $[3,4]$. The way of perceiving the role of the forest results from many regionally diversified conditions, including social, economic, socio-demographic, geographical and topographic ones [5]. Extensive research [5] in 5 European countries (England, Austria, France, Germany and Italy) showed that under the social assessment of the role of forests, protective functions against natural threats (avalanches, erosion, floods), as well as the preservation of biodiversity and the surface of forests were perceived as very important in all countries. The supply of timber and the availability of forest areas for rest and recreation were perceived as important. This demonstrates the need to plan and implement a socially acceptable strategy for sustainable forest management [6,7]. Social expectations regarding the role and management of forests in the objects subject to high environmental pressure are similar [8].

In the current reality of forestry, there is an increase in threats and risks caused, among others, by climate change, the growing intensity of damage occurring in forests and in forest environment [9-17]. In Central Europe, problems concentrate around boreal species-mostly Norway spruce (Picea abies (L.) H.Karst)-however, Scots pine (Pinus sylvestris L.) is also endangered. As the population increases and civilisation develops, the competitiveness of the forestry function increases, especially the production tasks and requirements of nature, landscape and climate protection $[18,19]$. The problem of planning complexity in forestry emerges [20]. The need to balance forest services (scope, intensity), taking into account the condition of stands and the desired direction of resources development, is becoming increasingly important. Therefore, the role of forest management in promoting the idea of sustainable forest management is growing [21-24]. Its philosophy is embedded in multifunctional forest model (MFM), widely approved and socially accepted in Europe [25-27]. Objectives of MFM should constitute important conditions for promoting sustainable development of forestry and should set priorities for economic tasks and adaptation of forest ecosystems to new challenges [28]. Production targets and tasks play an important role in this respect [22]. Their importance should be perceived in two ways: Ad hoc, by providing the necessary raw material and strategically, as an instrument shaping the desired direction of resources development. The manner of forest management directly influences the age structure and condition of stands, including species composition and inventory condition [29]. The indirect effect manifests itself in the form of changes in the stability and natural values as well as in the biodiversity of forest ecosystems [30]. Forest use is therefore the main instrument to support all the functions expected by society but it has to be based on good decision support systems-e.g., Multiple Criteria Decision Making (MCDM) [31-33].

In Polish forest management, the regulation of logging use is based primarily on the rotation (based on the age of stands) and the maintenance of spatial structure in the forest complex. The forest functions (protective forests and reserves) on which the management division is based (into FMU—forest management units) are taken into account with the view to calculating the annual allowable cutting size.

The aim of the paper is to propose and test the method of regulation of forest logging use. The concept assumes maintaining a relative uniformity of use, integrated with the improvement of the age structure and condition of wood resources. This method gives the opportunity of resilience thinking for the forest manager in planning of forest logging. It moves away from age limits or tree-size limits of forest production and instead looks at the status of every forest stand (bottom-up approach). At the same time, it allows the planning of long-term management with the uniformity of use in a chosen forest region (top-down).

The specific characteristics of objectives of the various forms and requirements related to the mandatory use of cuts in the forest management process (logging, pre-logging, salvage) limits the possibility of meeting the objectives of this concept only to logging cuts. The requirement to improve the condition of stands (stability, biodiversity) applies in particular to the tasks of forest owners within the framework of thinning [30,34,35]. 
In terms of practical utility, the proposed concept should enable forest managers at different levels to actively control the development of resources. This applies in particular to forest objects with predominantly Scots pine and Norway spruce stands which are, for most cases, main objects of conversion. They require imagination in the planning and consequence in the implementation of economic measures (growing, protection, use), so as to reduce the risk of disturbances in their growth and development.

\section{Materials and Methods}

The object of the research (forests of Regional Directorate of State Forests in Katowice "RDSF Katowice", over 500 thousand ha) is located in the southern part of Poland, mainly in the region of Silesia. It is a region with the highest population density rates-370 people per $\mathrm{km}^{2}$ (with the average for Poland amounting to 123) and urbanisation of 77\% (with the average for Poland amounting to $61 \%$ ). This results in a low index of forest area share per person -0.11 ha (the national average is $0.25 \mathrm{ha}$ ). The predominant share of Scots pine and Norway spruce makes these areas characterised by a high regional risk of damage $[36,37]$. They are heavily exposed to air, soil and water pollution due to the mining and mineral processing industries [38]. These forests are therefore clearly influenced by abiotic, biotic and anthropogenic factors ( $98 \%$ forest stands shows signs of damage) and they are an example of problems known from other European regions: Especially the Czech Republic and Germany. Mining damages in forests are typical for coal mining regions and are economical part of costs of life cycle of coal [39]. Forest areas are located in the immediate vicinity of large urban agglomerations and besides mentioned above harsh conditions are subject to high social pressure by recreation and tourism [40].

The afforestation in this region is $30.4 \%$ (typical for Poland), the average age of stands is 61.5 years (SD 35.4 years) and the average growing stock is about $245 \mathrm{~m}^{3} /$ ha (both values are lower than typical Polish ones, due to the domination of post-war and post-agricultural stands).

The structure of age classes is dominated by middle-aged stands. Age class III (41-60) is dominant. The share of age class II (21-40) and age class IV (61-80) is also significant. Stands over 100 years old occupy a small area (far left pane of Figure 1).

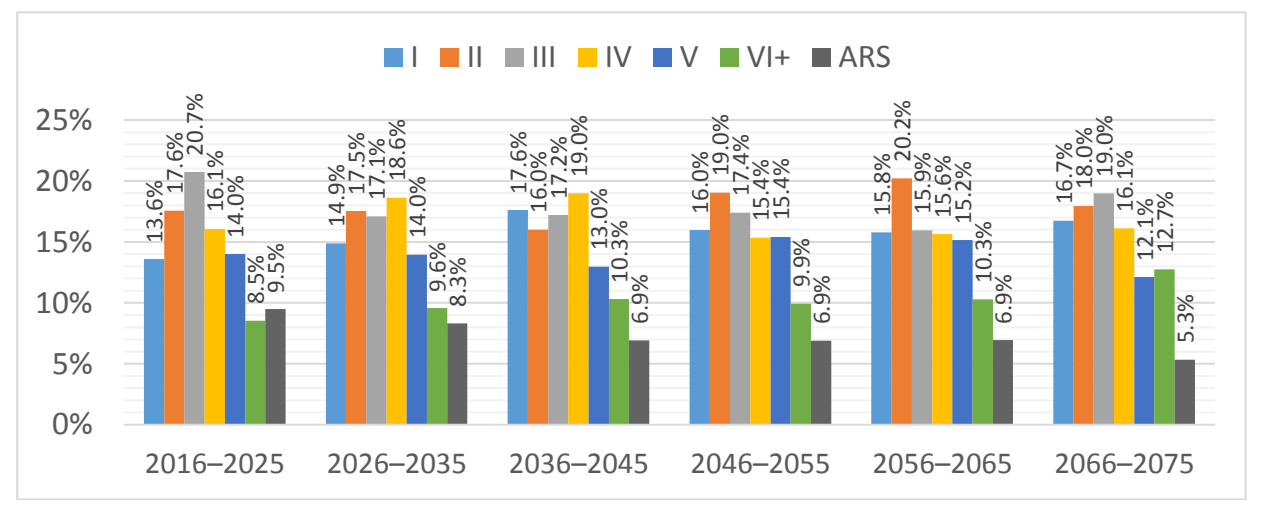

Figure 1. Anticipated changes in the structure of age classes area in the period 2016-2075 following today's rules. (ARS-Actually Regenerating Stands).

The individualistic resources development forecast was prepared for every forest stand on the basis of data published in the State Forests Information System (SFIS-The State Forests Information System in Poland contains data on the taxonomic characteristics of each stand, which are updated after each economic year using appropriate procedures). The basis for preparing forecasts of changes in the balance of resources and the volume of forest use were updated forest stand parameters. It has taken into account current legislation and forest practice-the spatio-temporal possibility of felling cuts and the following regeneration. No climate change scenario was taken into consideration as this was not the purpose of the study. Data was then gathered to age classes to be more easily analysed 
and compared. However, any model suitable for local conditions or that is already of use in region of interest can be used for further analysis. Moreover, to get more insight of climate changes results on cutting volume in region, different climate scenarios can be used as well.

The proposed concept of the use regulation assumes that the regulation period should cover at least a half of the rotation (the period of 60 years was assumed). The projected size of the cuts took into account economic periods of 10 years. It was assumed that the relative uniformity of yield of logging land in the adopted regulation period can be ensured by a mean value of logging use (MLU) calculated on the basis of the following formula:

$$
M L U_{j}=\sum \frac{F L U_{i}}{n}
$$

where:

$M L U_{j}$ - mean yield value determined for possible time periods of regulation " $\mathrm{j}$," for purpose of this study 2016-2075,

$F L U_{i}$ - use forecast for 10-year forecast periods " $i$,"

$n$-number of forecast periods, for purpose of this study $(i=6)$.

The mean value made it possible-for individual 10-year economic periods-to determine the differences between the mean value and the forecast $\left(R_{i}\right)$ using the formula:

$$
R_{i}=M L U_{j}-F L U_{i}
$$

where: The designations are as in the previous model.

The discrepancies found may be positive or negative, depending on the relationship between the forecast use and the mean value. A positive sign means that the yield can be increased during this period, theoretically to the mean value. A negative sign indicates that the forecast cut size for the period is higher than the mean value. The principle of relative uniformity shall be observed by balancing the determined discrepancies. This requires a decision on how much the logging use should be increased (positive relationships) or how it should be reduced in the reverse situation. Both of these possibilities can be used optionally, depending on the size of the discrepancy and the share of stands requiring urgent intervention and selected for longer standing. In both cases, the solution increases the planning freedom of the location of cuts, especially in the case of frequent disturbances in the spatial structure of the forest.

An important element of the research was the development of principles for reliable assessment of the condition of stands. The general concept of the assessment is presented in a publication by Łopiński and Stępień [41] and it has been tested and modified (e.g., assessment of stand compatibility with the site type). Indices and criteria of diagnostic and forecasting value should ensure the usefulness of assessment results for the promotion and control of the effects of sustainable forest management. In the diagnostic sense, it is about assessing the "cause-and-effect" relationship. The diagnostic value is to facilitate condition analysis and indication of future actions. These prerequisites are met by a 3-digit code, which is the result of the assessment of the main adopted characteristics. In practical terms, the numerical code of the total score fulfilled a double role: As a criterion for selection of stands and as a criterion for assessing the impact of the implemented economic measures on the improvement of the condition of resources. The assessment was carried out in the tree stand system starting from the II age class. The reason was the inability to apply the adopted assessment concept in the youngest stages of development. The methodological assumptions of the concept are presented in Table 1. 
Table 1. Criteria for comprehensive stand assessment.

\begin{tabular}{|c|c|c|c|}
\hline Main Characteristic & Symbol & Description & Weight \\
\hline $\begin{array}{l}\text { Index of achievement of the } \\
\text { growing objective (characteristic A) }\end{array}$ & A & $\begin{array}{l}\text { Compatibility of species composition with } \\
\text { stand type (ST) }\end{array}$ & 1.0 \\
\hline \multirow{5}{*}{ Standstability (characteristic B) } & B1 & $\begin{array}{l}\text { Compatibility of the actual forest } \\
\text { phytocoenosis with the reference standard }\end{array}$ & 0.3 \\
\hline & B2 & Degree of stand damage & 0.3 \\
\hline & B3 & Degree of diversity of composition & 0.2 \\
\hline & B4 & Mechanical stability $\left(\mathrm{H} / \mathrm{D}_{1.3}\right)$ & 0.1 \\
\hline & B5 & Density & 0.1 \\
\hline \multirow{2}{*}{$\begin{array}{l}\text { Size and condition of growing } \\
\text { stock (characteristic C) }\end{array}$} & $\mathrm{C} 1$ & Stocking & 0.5 \\
\hline & $\mathrm{C} 2$ & Stand quality & 0.5 \\
\hline
\end{tabular}

The evaluation was carried out taking into account three main characteristics (A, B, C), using a three-degree scale of differentiation. The above-mentioned degrees correspond to:

- the degree of achievement of the growing objective (characteristic A); a distinction was made between compliant (1), partially compliant (2) and non-compliant (3) grades,

- $\quad$ stability of stands (characteristic B); it was the resultant of 5 auxiliary partial determinants; stable (1), unstable (2) and endangered (3) conditions were distinguished,

- growing stock (characteristic $C$ ); was determined on the basis of 2 auxiliary determinants: good (1), medium (2) and poor (3) stock were distinguished.

The partial determinants provide a more detailed assessment of the main characteristic. Each of them has been conventionally assigned an appropriate weight. The sum of the weights of the partial determinants for each main characteristic has been found to be the same (it was 1.0). The source material for the assessment corresponded to the data from the taxonomy description tables obtained from the State Forests Information System (SFIS).

Characteristic $A-$ degree of achievement of the growing objective

A-compatibility of species composition with the stand type (ST): Compliant composition (1 score), partially compliant composition ( 2 scores) and non-compliant composition (3 scores).

Characteristic $B$ - stability of stands

B1-compatibility of real forest phytocoenosis with the reference method was evaluated according to the "habitat-age-structural" (HAS) method developed by Zielony [42]. A distinction was made between compliant phytocoenoses " 1 ," partially compliant " $2 a$ " and " $2 b$," and non-compliant phytocoenoses " $3 a$ " and " $3 b$," with " $a$ " being the neutral condition and " $b$ " the negative one. The following scoring rules were adopted: Compliant phytocoenoses-1 score, marked with " $2 \mathrm{a}$ " and " $3 a$ " -2 scores, " $2 b$ " and " $3 b$ " -3 scores.

B2 - tree stand damage degree [43]—individual damage levels were assigned the following scores: grade " 0 " or " 1 " ( 1 score) grade " 2 " ( 2 scores), grade " 3 " ( 3 scores).

B3-degree of diversity (richness) of species composition; determined on the basis of the relative diversity index $\left(R_{j s}\right)$, which is based on the relation between the actual Shannon-Wiener diversity index $\left(H r z_{j s}\right)$ and the desired (model) value of the diversity index $\left(M p_{s}\right)$. The value of the relative diversity index $(R j)$ was estimated on the basis of the formula:

$$
R_{j s}=H r z_{j s} / M p_{s}
$$

where: $\mathrm{Hrz}_{\mathrm{j}}$ - the actual value of the tree stand diversity index " $\mathrm{j}$ " in the habitat " $\mathrm{s}$ " according to Shannon-Wiener, determined by the formula [44]:

$$
H r z_{j s}=-\sum p_{i j s} \times \ln p_{i j s}
$$

where:

$p_{i j s}$ - the share of species ' $i$ ' in stand ' $j$ ' of the habitat ' $s$ ', 
$M p_{s}$ - model size of the diversity index in the habitat 's.'

The model value of the diversity index for particular habitats $\left(M p_{s}\right)$ was determined on the basis of the composition of regenerations recommended for a given habitat [45]. The following formula was used to calculate this index:

$$
M p_{s}=-\sum p_{i s} \times \ln p_{i s}
$$

where: $p_{i s}$-proportion of species ' $i$ ' recommended in the composition of the regenerations for habitat ' $s$ '.

$M p_{s}$ values were determined for particular forest habitat types taking into account the indicative regeneration compositions adopted at the Plan Assumptions Commission (PAC). For example, the desired $M p$ index for selected habitat forest types was 0.34 (Bs—dry coniferous forest), 0.36 (Bśw—fresh coniferous forest), 0.54 (BMśw—mixed fresh coniferous forest), 0.77 (LMśw—mixed fresh forest) and 0.96 (Lśw, Lw-fresh forest, humid forest).

On the basis of the size of the relative diversity index, the following stands were distinguished: diversified (class $1-R j \geq 0.8$ ), varied (class $2-R j=0.6-0.7$ ) and homogeneous (class $3-R j<0.6$ ).

B4-mechanical stability (tapered timber) $\mathrm{Zb}$; calculated as the mean index of tapered timber of the species prevalent on the basis of the average height $\mathrm{H}(\mathrm{cm})$ and the average diameter at breast height D1.3 using the formula: $\mathrm{Zb}=\mathrm{H} / \mathrm{D} 1.3$. Taking into account the $\mathrm{Zb}$-factor value, three stands were distinguished [46]: Stands that were stable enough $(\mathrm{Zb} \leq 80)$, stands that were unstable enough $(80<\mathrm{Zb} \leq 100)$ and endangered stands $(\mathrm{Zb}>100)$ that were awarded respectively 1,2 or 3 scores.

B5-stand density; it is determined during the management works according to the provisions of [43]. Three classes of density were distinguished: Large, moderate, moderate, sometimes large, moderate sometimes intermittent (1 score); very large, intermittent, intermittent sometimes moderate ( 2 scores) and excessive, intermittent sometimes open ( 3 scores).

Characteristic $C$ - size and condition of the growing stock.

C1-the stocking for the upper layer of the stand was taken into account. On this basis, stands with $\mathrm{Zd} \geq 0.8$ (group 1), $\mathrm{Zd}=0.5-0.7$ (group 2) and $\mathrm{Zd} \leq 0.5$ (group 3) were distinguished and assigned 1,2 and 3 scores respectively. Stands in regeneration class and stands in the assigned for regeneration class were included in group 1.

C2-the growing and technical quality of the stand was adopted from the SFIS. The stands were divided into 3 classes using the following classification key: Growing quality 11, 12, 13, 21, 22 and technical quality $1-1$ score, growing quality $14,23,24,31,32,33,34$ and technical quality $2-2$ scores, growing quality $41,42,43,44$ and technical quality 3 or $4-3$ scores.

The applied evaluation criteria and scoring rules enable the recognition of the share of stands according to the 3-digit code of the total score $\left(P_{j}\right)$. The assessment was carried out for stands from the II age class, taking into account as the production function as the dominant one. Each stand is given a three-digit code as the final result of the assessment, with a general form:

$$
P_{j}=\left[A_{j}, B_{j}, C_{j}\right]
$$

where:

$A_{j}, B_{j}, C_{j}$-the result of the assessment of the achievement of the growing objective, the condition of stability and stock of the stand " $j$." Weighted averages of the partial determinants were used to calculate the score of the main characteristics $B$ and $C$.

Elementary possible events under the total score can be presented in the 27-element matrix P:

$$
P=\left[\begin{array}{lllllllll}
111 & 121 & 131 & 211 & 221 & 231 & 311 & 321 & 331 \\
112 & 122 & 132 & 212 & 222 & 232 & 312 & 322 & 332 \\
113 & 123 & 133 & 213 & 223 & 233 & 313 & 323 & 333
\end{array}\right]
$$

The classification of stands in terms of needs and urgency of intervention and selection for longer standing shall be based on the codes for total score $\left(P_{j}\right)$. It was the basis for their division into 3 groups: 
without the need for intervention (group 1), with a need for non-urgent intervention (group 2) and with a need for urgent intervention (group 3). For this purpose, the following classification key was conventionally used:

- $\quad$ group 1-111, 112, 121, 122, 211, 212,

- $\quad$ group 2-113, 123, 131, 132, 213, 221, 222, 311, 312.

- $\quad$ group 3-133, 223, 231, 232, 233, 313, 321, 322, 323, 331, 332, 333.

Group 1 stands provided a potential basis for selecting those that met the requirements for extending their standing.

Example of an interpretation:

CODE 132 means: $\mathrm{A}=1$ (achievement of the growing objective in the satisfying degree), $\mathrm{B}=3$ (unstable stand), $\mathrm{C}=2$ (mean growing stock).

\section{Results}

\subsection{Changes in the Age Structure}

The current structure of the age classes is unsatisfactory (Figure 1). The dominant stands are those of the second and third age classes. There is a significant shortage of stands of the VI and older age classes and of the I age class. The forecast of changes in the surface structure of age classes in the perspective of the coming 60 years indicates some equalisation of the share of particular age classes.

Although we are aware that it is not possible to achieve the structure of a normal forest (normal structure of age classes), we should strive to make the area distribution in terms of age classes as uniform as possible. From the point of view of use control, this ensures durability and uniformity of use in specific periods of time.

\subsection{The Forecast of Yield Scope and Relative Uniformity of Use}

The scope of logging use in 2016-2075, determined for particular 10-year forecast periods, increases over the entire period from about 16 to about 20 million $\mathrm{m}^{3}$ of net merchantable timber. The mean value of logging use (MLU) calculated for the entire regulation period (2016-2075) is 18.4 million $\mathrm{m}^{3}$ of net merchantable timber per 10 years. The relationship between the mean value and the scope of logging cuts forecast for the individual economic periods $\left(\mathrm{FLU}_{\mathrm{i}}\right)$ is illustrated in Figure 2.

The discrepancies $\left(R_{i}\right)$ in the period 2015-2045 are positive. On the other hand, discrepancies with the negative sign were found in the years 2046-2075. This means that maintaining a uniform logging use over the entire control period enables the annual volume of cuts to be increased in the first three decades by approximately 238, 113 and 15 thousand $\mathrm{m}^{3}$ of net merchantable timber, respectively. In the next three decades, the net merchantable timber shall be decreased by approx. 52, 134 and 181 thousand $\mathrm{m}^{3}$ annually. 


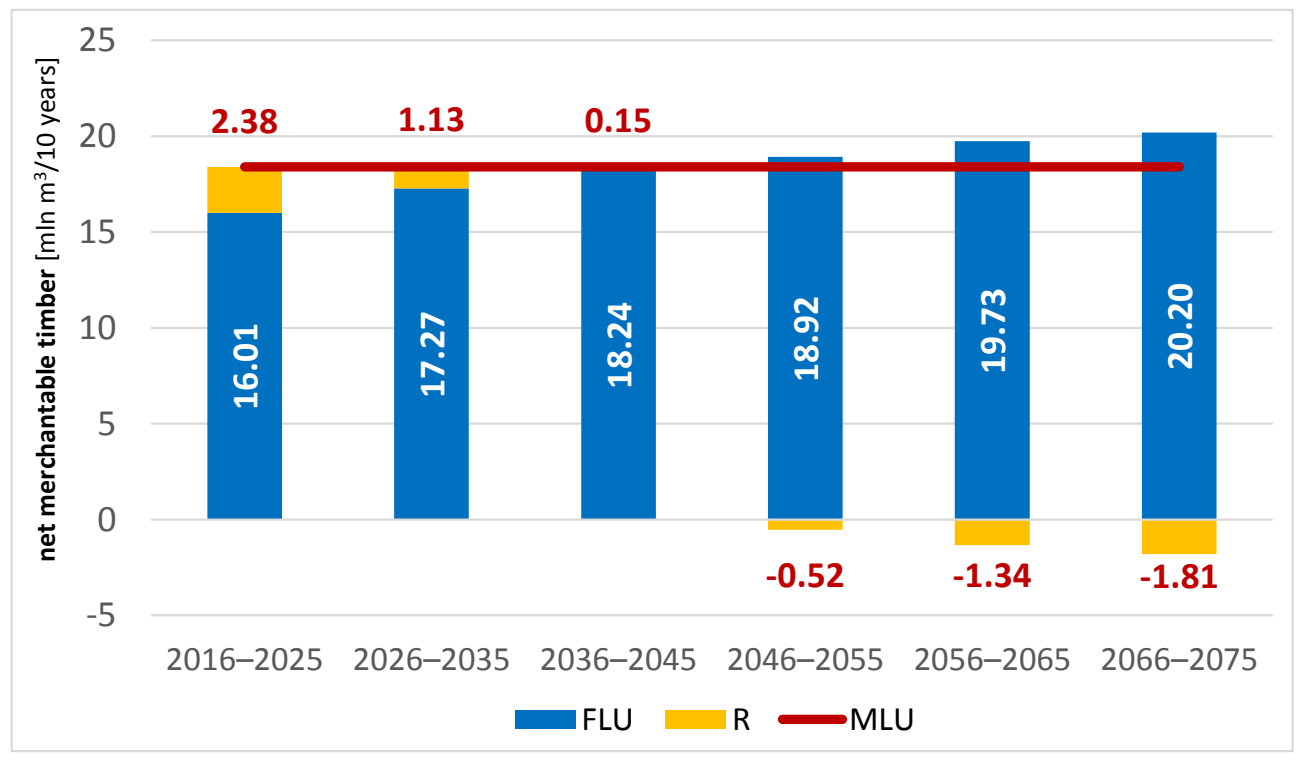

Figure 2. The discrepancies (R) between the average (MLU) and the forecast scope of cuts (FLU) in the period of 2016-2075.

\subsection{Stand Structure According to Needs and Urgency of Intervention}

Stands without the need for intervention (group 1) cover $277,913.92$ ha (about $55 \%$ of the total area). The dominant stands are those with codes 112, 121 and 122. Stands in group 2 occupy 182,350.55 ha, which is about $36 \%$ (the vast majority are stands with code 222). Urgent intervention was found to be necessary in stands covering an area of $47,242.28$ ha $(9.3 \%)$, of which $2 / 3$ corresponded to stands with codes 322 and 223.

\subsection{Structure and Urgency of Intervention by Age Class}

The share of stands without intervention needs varies from about $50 \%$ in stands which are 21-60 years old (II and III age class) to about $60 \%$ in older stands, with the mean value for all stands being about $55 \%$ (Figure 3). A similar diversity was found in the group of stands with non-urgent intervention need. Their share varies from about 30\% (age class IV) to about $40 \%$ (IIa and IIIa), with an average of about $36 \%$. The share of stands requiring urgent intervention ranges from about $7 \%(\mathrm{VI}+)$ to about $11 \%$ in younger stands, with the average of approximately $9 \%$. 


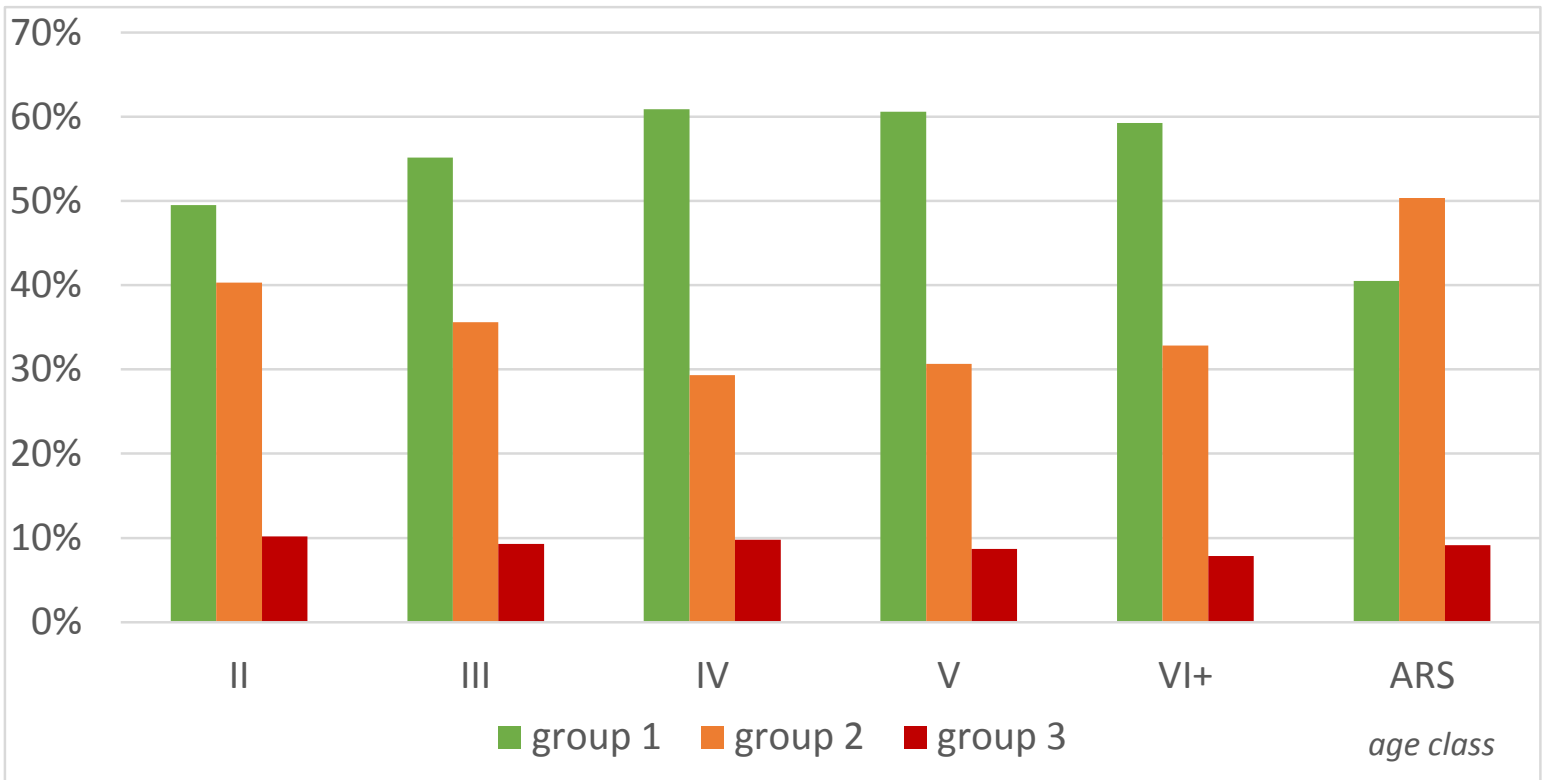

Figure 3. Need and urgency of intervention in stands of different age classes.

\subsection{Structure and Urgency of Intervention by Species}

In the case of stands without any intervention (group 1), pine and beech trees predominate (Figure 4). A significant share of stands in this group also correspond to silver fir (Abies alba Mill.) and oak species (Quercus robur L. and Quercus petraea (Matt.) Liebl.) stands. The area of Scots pine and European beech (Fagus sylvatica L.) that stands in group 2 (about 30\%) is close to the average and the area of Norway spruce, oak and alder (Alnus Mill.) stands is higher and amounts to $50 \%-60 \%$.

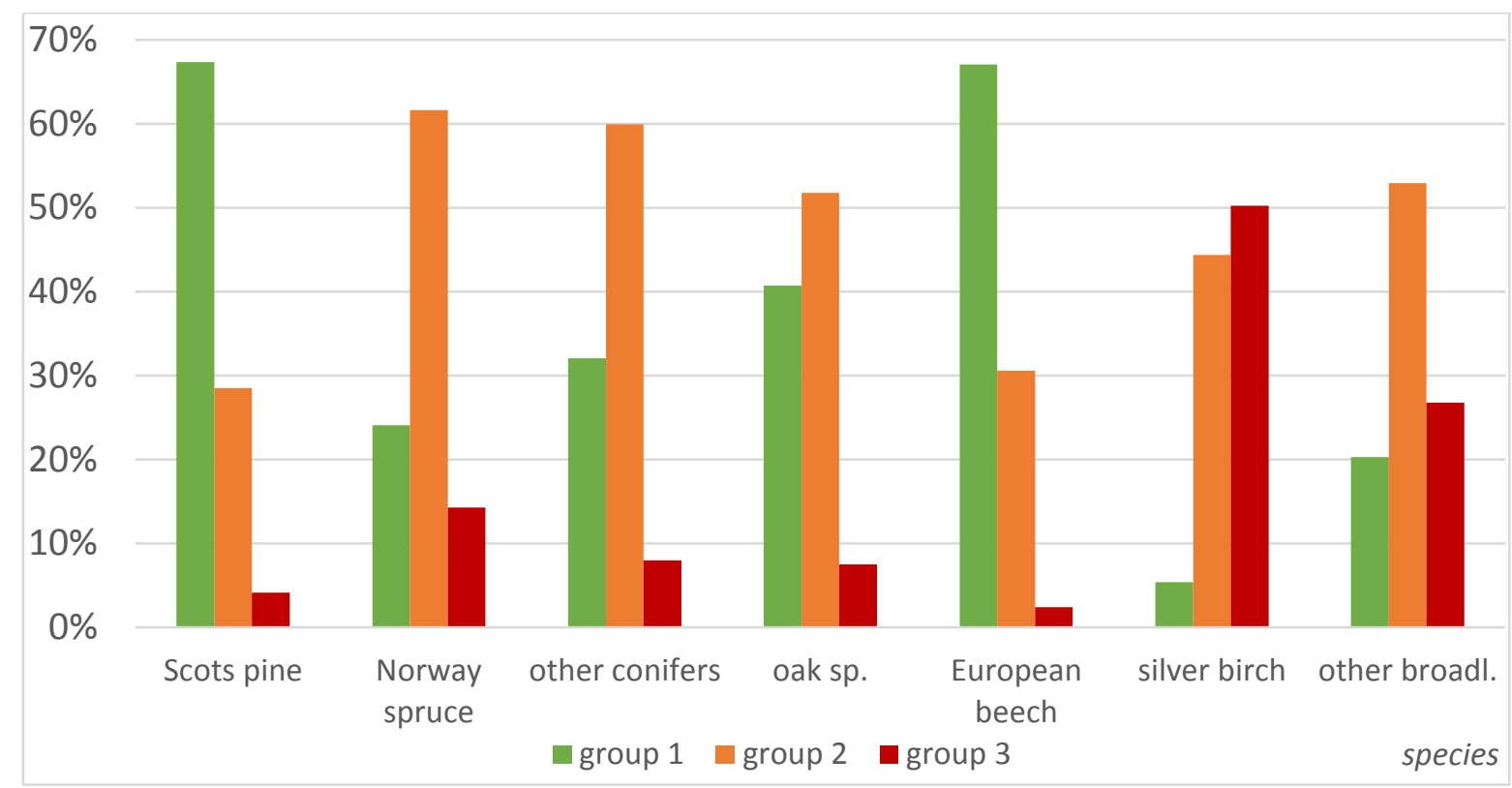

Figure 4. Need and urgency of intervention in stands according to the prevailing species.

In stands requiring urgent intervention (group 3), the lowest values are recorded for European beech, silver fir and Scots pine stands (about $2 \%-4 \%$ ) and oaks (pedunculate and sessile) stands (over $7 \%$ ). The highest are silver birch (Betula pendula Roth)—over 50\%, Norway spruce and alder stands (about $15 \%$ and $10 \%$ respectively). 


\section{Discussion}

Three methodically consistent stages were distinguished in the proposed concept. First, the individualistic forecasts of resources development and the forecasts of the scope of forest use were prepared. Secondly, new assumptions for the regulation of logging use that follow uniformity in long-term were proposed. At the third stage, a comprehensive assessment of the condition of stands was carried out with respect to the diversity of needs and urgency of growing and protective measures. The results of the assessment were used to identify stands where-irrespective of age- the need for intervention was considered to be urgent. The results of the evaluation were also the basis for the selection of stands for longer standing. Anticipated result of this long-term intervention is the improved age structure and natural values of the forest, including biodiversity and resilience. The latter is of highest importance nowadays.

In the current reality of forestry, threats to forest sustainability caused by negative influence of biotic, abiotic and anthropogenic factors are intensifying. Moreover, there is an increase in social expectations concerning the role and tasks of forests, with the generally negative perception of foresters' activities related to forest use and obtaining timber. Therefore, in the process of implementation of the assumptions of the SF Strategy for 2014-2030 in Poland [47], the problems of forest maintenance and pro-ecological development became a major challenge for management planning. It is believed that all planning decisions, especially those concerning forest use, should be the resultant of analyses respecting economic, environmental and social criteria [48]. Such decisions shall be an important element of promoting sustainable development and maintenance of the forest as well as shall reduce the risk of forest management by shaping the stability and enrichment of biodiversity (among others). In this respect, it is necessary to change the perception of the role and tasks of forest management. Management in such an approach cannot exclude the production function or other forms of forest resource use [49]. On the other hand, the measures taken should contribute to minimising the natural, economic, ecological and protective contradictions related to the implementation of economic tasks, including the ones related to scope, deadline and intensity [50].

The requirements formulated in such a way are a new problem in a theoretical and practical sense. The first aspect concerns the selection of criteria and indices necessary to objectivize decisions in planning and conducting sustainable management in the multifunctional forest model [51-54], especially based on stand level [55]. When working on that issue it was assumed that all functions of the forest in this object should be treated equally. Therefore, the significance of the adopted features of stand condition assessment in shaping the functional potential was treated in a similar way. From the group of numerous, often unmeasurable characteristics, the selection criteria were met by those of a diagnostic value, such as identification of the type and cause of the phenomenon and its forecast usefulness, including risk recognition and development forecasting [56,57]. The decision to choose such characteristics was justified by the fact that the desired development of resources in this region is determined by the indices of the implementation of growing objectives, the stability and the natural values, as well as the size and condition of the forest stands stock. Practical reasons also justified this choice. The selection of stands requiring prior intervention and selection for longer standing was carried out on the basis of information from forest inventory descriptions of SFIS [58]. They were used directly—for quantitative assessment and indirectly—for the assessment of qualitative characteristics of resources, including stability and diversity.

Long-term prognosis that helps to achieve the uniformity of use is a good support mechanism. Using this technique together with proposed coding gives us opportunity to respond to ecological problems in the forest as well as market demand. From economical point of view if this demand is lower than normal then, we can stop cuts in stands showing exceptional natural and health values (high status); however, if it is the opposite there is a pool of stands that we should consider for rebuilding (low status), thus rise up the amount of wood on the market. This gives us a tool we are able to respond to market demand and therefore keep the prices and profitability stable. 
The stand status that we have analysed by codes show us that as age of each stand rises the overall mark is getting better. Our explanation is that stands of lower age are more prone to damage and instability (lower resilience) and that they need special focus and care. Last group (Figure 3)-Actually Regenerating Stands (ARS) - is a special group that is currently undergoing long term cutting and regeneration process, therefore its code status is lower than other groups. We can assess the full results of this interventions only after they are finished.

The dominance of pine and beech among tree stands with low conversion needs (Figure 4), results from the specificity of species composition compliance with site type (poor soils for pine and mesotrophic for beech). The negative assessment of silver birch stands results from forest policy decisions that do not support this species on fertile sites or from post-agricultural history of silver birch stands.

The usefulness of codes determined for forest stands has been widely proven in research and practice [31,48]. The risk of wind damage in boreal forests was investigated in Finland [59]. In North China, tree stands for harvesting at a landscape level were defined in a similar way [60], using decision support system, FORESTAR [61]. Costa Freitas [62] used a three-element assessment of risk (fire), biodiversity and profitability of forest management in the Mediterranean forests in the south of Portugal. Multi-analysis of forest use intensity and tourist pressure indicators enabled Eggers [63] to propose various scenarios for forest management in southern Sweden. The idea of coding the forest is not new, however it gives us opportunity to describe full potential of each forest precisely with digits that allow us to order and compare different stands.

The interpretation key used in this paper to assess the extent to which the growing objective has been achieved (characteristic $A$ ) and to assess the stability of the stand (characteristic $B$ ) is an expression of a certain liberalization. In the first case, this concerns stands with total score codes 211 and 212. They were included in the group which did not require any intervention. This is due to the conviction that in a multifunctional forest the problem of composition consistency in forest management is slightly less important $[22,34,64]$. In the second case, the set of stands in which the intervention was considered to be non-urgent included those which obtained a positive result of the assessment of characteristics $A$ and $C$ (codes 131 and 132), despite the threat to stability. The proposed assessment of the compatibility of real forest phytocoenosis with the baseline (partial determinant $B 1$ ) is also a sign of certain liberalisation in this respect. Taking into account the social expectations regarding the natural values of the forest, the assessment of stands prioritised the diversity of species composition (partial determinant B3). The ranges of diversity class ranges in the proposed assessment concept may be adopted flexibly, depending on the values determined in the stands of a given object. The design of the formula for calculating the richness index is mathematically universal $\left(-\sum(p i \times \ln p i)\right)$. It requires the knowledge of the share of species forming the stand, without the need to differentiate their genera. Their share may be determined, inter alia, by a relative index (\%), the number of trees, the section area or the cubic volume. The calculated index for stands with the same number of species and their share in the composition is mathematically identical. Therefore, it is more useful to assess the overall natural diversity than to assess the potential of the production function.

One of the drawbacks of the applied methodology of stability assessment is the imposition of an unreliable method of estimating the density of stands. Due to the lack of data on the number of trees, the verbal description of the differentiation of this determinant (B5) was used. In the context of the stability assessment (characteristic $B$ ), it was assumed that a certain deficiency in this respect should be compensated by a partial indication of the mechanical stability of the stand H/D (B4). The values of stands in the economic sense express the condition of stock (characteristic $C$ ) through partial determinants, that is, "afforestation." (C1) and the growing or technical quality of the stand (C2).

Balancing the discrepancies between the average and the forecast value requires taking a decision focused on the stage of planning and implementation of tasks. The basic decisions concern the uniformity of logging use. What is important in this respect is the decision if we want to increase or decrease the yield within the "average—forecast" range. This requires in-depth analysis, taking 
into account, among others, the nature and extent of the discrepancies, the trend in the use forecasts, the proportion and structure of stands requiring urgent intervention and the possibility of selecting stands for standing. In addition, spatial and organisational opportunities for the implementation of increased yield as well as the situation on the timber market (demand, prices) should also be taken into account. This issue should be resolved by the appropriate level of forest management (General Directorate of State Forests, RDSF, forest inspectorates). The proposed concept should provide forest managers at various levels with the direct possibility of actively steering the development of resources. This applies in particular to numerous objects in Poland, which are dominated by pine and spruce stands. They require consistent implementation of economic measures (growing, protection, use), aimed at the reduction of the risk of disturbance of their growth and development. An important task in this situation is to identify growing needs and monitor the impact of maintenance on changes, such as the stability and biodiversity of stands. The vision of future stability is being developed already at the stage of regeneration works [65]. The implementation of this vision should be supported by the local manager throughout the entire period of standing natural production [30]. However, the growing and protective procedures planned to be performed do not constitute an isolated stage of implementation. The current state of needs is important. Past events are of great importance in forestry. Therefore, it is important that the manner, timing, intensity, urgency and sequence of treatments are continuous in terms of chronology.

Conditionality of selection of criteria and assessment indices in examples of solutions from the region of Central Europe, including Austria, Germany and Switzerland, determines the usefulness in the context of the needs of the analysed problems $[53,66]$. The criteria used in the present study to assess stands are a compromise and a useful solution:

- in the sense of the general assumptions for the assessment of the correctness of forest management (nachhaltige Waldbewirtschaftung) ([67] after [53]),

- in terms of the possibility to control the principles of sustainable management, the selection of criteria refers to the solutions applied in Switzerland ([68] after [53]),

- in terms of stability and stock assessment, the auxiliary indicators used are an attempt to take into account the regional specificity applied in Germany (Nachhaltigketsindikatoren auf regionaler Ebene) [69] after [53].

The specificity of the objectives and requirements of the mandatory use of cuts (logging, pre-logging, salvage ones) in forest management limits the possibility of meeting all the assumptions of this concept. Maintaining the uniformity of acquisition and improving the age structure may only apply to logging cuts. The requirement to improve the condition of stands (stability, biodiversity) also applies to other forms of use, in particular pre-logging cuts $[30,49,70]$.

Forecasts of possible scenarios for the impact of climate change on forest ecosystems generally address the risks to their sustainable functioning. As a result of these changes, the vegetation period in Europe is extended and the limits of the natural range of trees as well as the spatial distribution of plant communities are shifted [22,71-73]. Global warming will increase the amount of energy in the atmosphere, which may cause increased threats caused by wind and intensification of the process of natural tree elimination [70]. Model studies [74] indicate serious global economic and economic effects of such transformations.

The hypothesis of the impact of climate change on the transformation of the species composition of stands in the last two centuries has been confirmed in numerous forest objects in Poland [75]. The results of research into the dynamics of changes in species composition and the structure of stands in the developed part of the Białowieża Forest [73] confirmed the expansion of the hornbeam and the subsidence of oak, pine and maple (among others). Thanks to the growing procedures carried out in the stands of this part of the Forest, the observed changes were not as large as in the area of the Strict Forest Reserve [72]. These studies confirmed the high risk to oaks (pedunculate and sessile), Scots pine, common ash (Fraxinus excelsior L.), Norway maple (Acer platanoides L.) and elms (Ulmus minor Mill., 
Ulmus laevis Pall. and Ulmus glabra Huds.) and aspens (Populus L.), indicating that these species were completely disappearing. The process of homogenization of the species composition and structure of stands and the disappearance of many elements of biodiversity were observed in the stands of the Forest.

The specificity of forestry is that the consequences of changes may appear in the long term. The problem of climate change and different biotic factors changing our management in along XXI century was shown in [76]. These changes are not related to timber volume and biodiversity only temporally but also spatially.

In view of the uncertainty as to the impact of potential climate changes on the competitive capacity of trees, opportunities should be sought to mitigate the risks and negative consequences through the use of anticipatory adaptation measures in the forest management strategy [22,77-81]. A new aspect in this search is the complexity of decisions typical for planning in forestry related to the choice of growing objectives, especially concerning the diversity of species composition as well as its productive and financial consequences [82]. In relation to the traditionally used method of forest management, the idea of ecosystem management is now gaining popularity, in which the principle of sustainability of forest services is replaced by the principle of sustainable preservation of ecosystems which provide these services [83]. The potential threats in the forest area of the object among include, among others, fluctuations in the groundwater level, excessive burden on forests with social functions and damage from animals. This raises the dilemma of how to reach a sustainable compromise in order to achieve one's own goals and meet social expectations. The idea of promoting the concept of sustainable management in a multifunctional forest was evaluated under the influence of the negative influence of the environment and changing social requirements over time. The content of the currently understood provisions refers to the definition of forest management (oekosystemare Nachhaltigkeitdeitfinition) ([84] after [85], [86] after [53]) and to the multifunctional forest management (nachhaltige Mehrzweckforstwirtschaft [53]). The extended contents of the provisions require the development of complex forest benefits (economic, social, cultural, aesthetic) through long-term and comprehensive protection of natural factors of production in quantitative and qualitative terms [85].

\section{Conclusions}

In the presented concept, the main regulatory element is the postulate of earlier logging intervention in problematic stands-regardless of their age and longer standing of some older stands, showing exceptional natural and health values. Inclusion of the concept of earlier intervention and longer retention into the process of regulating logging use will allow to maintain the uniformity and improvement of the balance of resources and enrich the natural values and biodiversity of forest ecosystems. The increase of the natural values of the forest takes place through the increase of the share of older stands, especially long-lived deciduous species (pedunculate and sessile oaks, European beech, Norway maple) and stable Scots pine stands growing in the appropriate habitats. This technique can be used to mitigate current and anticipated climate changes for nearest future. We can choose which stands, that are prone to changes that we observe or predict, need rebuilding. The limiting factor of that concept is that we can assess only forests that have adequate inventory data (e.g., forestry management plans).

The proposed concept supports the balancing of discrepancies resulting from the relation between the average and the forecast size of cuts and increases the pool of stands and the freedom to plan the location of cuts, especially in the case of spatial disturbances in forest structure. The combined assessment code provides an opportunity to assess the impact of relevant management measures on the condition of the stands and to develop the functional potential of the forest with the view to meeting the objectives of sustainable development in forestry in an improved way. However, because future status of stands is not known therefore we are not able to perform a full prognosis after proposed interventions. Instead, cutting size will evolve in time with stands status and stock prognosis. 
Overall, the concept proposes to combine bottom-up approach (examining every stand and checking its status) and top-down one (assessing the cutting size in long-term perspective) to work together for a more sustainable forestry management. Silesian region was chosen as an example of high pressure. The concept can be easily adopted in most places, using local forecasts and slightly adjusting assessment coding to local conditions.

Author Contributions: Conceptualization, T.B., Ł.Ł., W.K., M.O., R.W. and E.S.; Data curation, W.K.; Formal analysis, W.K.; Funding acquisition, T.B.; Investigation, T.B. and E.S.; Methodology, T.B., Ł.Ł., M.O., R.W. and E.S.; Supervision, T.B. and E.S.; Writing-original draft, T.B. and E.S.; Writing-review \& editing, W.K., M.O. and R.W.

Funding: This research was funded by the Polish State Forests research grant OR.271.3.8.2015 from 9 March 2015 to the Department of Forestry Management Planning, WULS-SGGW Faculty of Forestry.

Acknowledgments: Authors would like to thank two anonymous reviews whose comments helped improve and clarify this manuscript.

Conflicts of Interest: The authors declare no conflict of interest. The founding sponsors had no role in the design of the study; in the collection, analyses, or interpretation of data; in the writing of the manuscript and in the decision to publish the results.

\section{References and Notes}

1. Sheppard, S.R.J.; Meitner, M.J. Using multi-criteria analysis and visualization for sustainable forest management planning with stakeholder groups. For. Ecol. Manag. 2005, 207, 171-187. [CrossRef]

2. Przybylska, K.; Zięba, S. Las i gospodarka leśna w systemie planowania i zagospodarowania przestrzennego. Sylwan 2009, 12, 814-825.

3. Fischer, J.; Peterson, G.D.; Gardner, T.A.; Gordon, L.J.; Fazey, I.; Elmqvist, T.; Felton, A.; Folke, C.; Dovers, S. Integrating resilience thinking and optimisation for conservation. Trends Ecol. Evol. 2009, 24, 549-554. [CrossRef] [PubMed]

4. Rist, L.; Moel, J. Sustainability in forest management and a new role for resilience thinking. For. Ecol. Manag. 2013, 310, 416-427. [CrossRef]

5. Rametsteiner, E. Einstellungen zu Wald, Holz, Umwelt und Nachhaltigkeitszeichen in Oesterreich und in Europa; Band 34; Schriftenreihe des Instituts fuer Soziooekonomik der Forst- und Holzwirtschaft: Wien, Austria, 1998.

6. Boukherroub, T.; D'amours, S.; Ronnqvist, M. Sustainable forest management using decision theaters: Rethinking participatory planning. J. Clean. Prod. 2018, 179, 567-580. [CrossRef]

7. Marchi, E.; Chung, W.; Visser, R.; Abbas, D.; Nordfjell, T.; Mederski, P.; McEwan, A.; Brink, M.; Laschi, A. Sustainable Forest Operations (SFO): A new paradigm in a changing world and climate. Sci. Total Environ. 2018, 634, 1385-1397. [CrossRef] [PubMed]

8. Zundel, R. Die Bedeutung des Waldes in einem dicht besiedelten Industrieland (Dargestelt am Beispiel der BRD). Z. For. Fac. Univ. Istanb. Ser. A 1991, 41, 36-42.

9. Lindner, M.; Maroschek, M.; Netherer, S.; Kremer, A.; Barbati, A.; Garcia-Gonzalo, J.; Seidl, R.; Delzon, S.; Corona, P.; Kolström, M.; et al. Climate change impacts, adaptive capacity, and vulnerability of European forest ecosystems. For. Ecol. Manag. 2010, 259, 698-709. [CrossRef]

10. Milad, M.; Schaich, H.; Bürgi, M.; Konold, W. Climate change and nature conservation in Central European forests: A review of consequences, concepts and challenges. For. Ecol. Manag. 2011, 261, 829-843. [CrossRef]

11. Buma, B.; Wessman, C.A. Forest resilience, climate change, and opportunities for adaptation: A specific case of a general problem. For. Ecol. Manag. 2013, 306, 216-225. [CrossRef]

12. Munang, R.; Thiaw, I.; Alverson, K.; Liu, J.; Han, Z. The role of ecosystem services in climate change adaptation and disaster risk reduction. Curr. Opin. Environ. Sustain. 2013, 5, 47-52. [CrossRef]

13. Seidl, R.; Lexer, M.J. Forest management under climatic and social uncertainty: Trade-offs between reducing climate change impacts and fostering adaptive capacity. J. Environ. Manag. 2013, 114, 461-469. [CrossRef] [PubMed]

14. Lindner, M.; Fitzgerald, J.B.; Zimmermann, N.E.; Reyer, C.; Delzon, S.; van der Maaten, E.; Schelhaas, M.-J.; Lasch, P.; Eggers, J.; van der Maaten-Theunissen, M.; et al. Climate change and European forests: What do we know, what are the uncertainties, and what are the implications for forest management? J. Environ. Manag. 2014, 146, 69-83. [CrossRef] [PubMed] 
15. Bussotti, F.; Pollastrini, M.; Holland, V.; Brüggemann, W. Functional traits and adaptive capacity of European forests to climate change. Environ. Exp. Bot. 2015, 111, 91-113. [CrossRef]

16. Ding, H.; Chiabai, A.; Silvestri, S.; Nunes, P.A.L.D. Valuing climate change impacts on European forest ecosystems. Ecosyst. Serv. 2016, 18, 141-153. [CrossRef]

17. Sousa-Silva, R.; Verbista, B.; Lomba, Â.; Valent, P.; Suškevičs, M.; Picarde, O.; Hoogstra-Klein, M.A.; Cosofret, V.-C.; Bouriaud, L.; Ponette, Q.; et al. Adapting forest management to climate change in Europe: Linking perceptions to adaptive responses. For. Policy Econ. 2018, 90, 22-30. [CrossRef]

18. Minsch, J. Gesamtheitliche Betrachtungen zu tatsaechlichen und vermeintlichen Nutzungskonflikten im Wald. BUWAL, Schr.reihe Umw. 1992, 175, 67-89.

19. Mori, A.S.; Spies, T.A.; Sudmeier-Rieux, K.; Andrade, A. Reframing ecosystem management in the era of climate change: Issues and knowledge from forests. Biol. Conserv. 2013, 165, 115-127. [CrossRef]

20. Bachmann, P. Forstliche Planung-Heute und morgen. Schweiz. Z. Forstwes. 2005, 5, 137-141. [CrossRef]

21. Bachmann, P.; Amman, S.; Kunz, B.; Rupf, A. Moderne forstbetriebliche Planung. Schweiz. Z. For. 2002, 5, 184-185. [CrossRef]

22. Borecki, T.; Stępień, E. Ewolucja roli i aktualnych zadań urządzania lasu. Sylwan 2017, 161, 179-188.

23. Siry, J.P.; Cubbage, F.W.; Ahmed, M.R. Sustainable forest management: Global trends and opportunities. For. Policy Econ. 2005, 7, 551-561. [CrossRef]

24. MacDicken, K.G.; Sola, P.; Hall, J.E.; Sabogal, C.; Tadoum, M.; de Wasseige, C. Global progress toward sustainable forest management. For. Ecol. Manag. 2015, 352, 47-56. [CrossRef]

25. Pretzsch, H.; Grote, R.; Reineking, B.; Rotzer, T.; Seifert, S. Models for forest Ecosystem Management-A European perspective. Ann. Bot. 2007, 101,1-23. [CrossRef] [PubMed]

26. Szujecki, A. Kierunki rozwoju leśnictwa światowego i polskiego w XX i XXI wieku. Sylwan 2001, 9, 47-55.

27. Szujecki, A. Regionalne programy operacyjne polityki leśnej Państwa. Biblioteczka Leśniczego 2002, 175, 1-14.

28. United Nations. Global Indicator Framework for the Sustainable Development Goals and Targets of the 2030 Agenda for Sustainable Development. In Work of the Statistical Commission Pertaining to the 2030 Agenda for Sustainable Development (A/RES/71/313); United Nations: New York, NY, USA, 2017.

29. Klocek, A. Optymalizacja operatywnego planowania użytkowania rębnego drzewostanów. Folia For. Pol. Ser. A 1980, 24, 5-18.

30. Fonder, W. Wzmaganie stabilności drzewostanów metodami hodowlanymi. In Nowe Zasady Hodowli Lasu, 3rd ed.; Wyd. Świat: Warszawa, Poland, 2004; Volume 206, pp. 3-14.

31. Segura, M.; Ray, D.; Maroto, C. Decision support systems for forest management: A comparative analysis and assessment. Comput. Electron. Agric. 2014, 101, 55-67. [CrossRef]

32. Zhou, M. Adapting sustainable forest management to climate policy uncertainty: A conceptual framework. For. Policy Econ. 2015, 59, 66-74. [CrossRef]

33. Nobre, S.; Eriksson, L.-O.; Trubins, R. The Use of Decision Support Systems in Forest Management: Analysis of FORSYS Country Reports. Forests 2016, 7, 72. [CrossRef]

34. Bernadzki, E. Cele hodowli lasu wczoraj i dziś. Sylwan 1997, 4, $23-31$.

35. Borecki, T.; Pieniak, D.; Stępień, E.; Wójcik, R. Planning and regulation of pre-final cuttings in Poland-A proposal for change. Folia For. Pol. Ser. A For. 2017, 59, 265-271. [CrossRef]

36. Bruchwald, A.; Dmyterko, E. Ryzyko powstawania szkód w drzewostanach poszczególnych nadleśnictw Polski. Sylwan 2012, 156, 19-27.

37. Orzechowski, M.; Wójcik, R. Regionalne zróżnicowanie ryzyka wystapienia uszkodzeń drzewostanów w Polsce. Stud. Mater. Cent. Eduk. Przyr.-Leś. 2014, 39, 44-54.

38. Szczepanska, J.; Twardowska, I. Distribution and environmental impact of coal-mining wastes in Upper Silesia, Poland. Environ. Geol. 1999, 3, 249-258. [CrossRef]

39. Epstein, P.R.; Buonocore, J.J.; Eckerle, K.; Hendryx, M.; Stout, B.M., III; Heinberg, R.; Clapp, R.W.; May, B.; Reinhart, N.L.; Ahern, M.M.; et al. Full cost accounting for the life cycle of coal. Ann. N. Y. Acad. Sci. 2011, 1219, 73-98. [CrossRef] [PubMed]

40. Zięba, S. Regionalne strategie zrównoważonego rozwoju gospodarki leśnej. Studium metodologiczne i zastosowanie w warunkach Polski. Zeszyty Naukowe UR im. H. Kotłataja w Krakowie 2012, 496, 373.

41. Łopiński, Ł.; Stępień, E. Koncepcja kwalifikowania drzewostanów do przebudowy. Sylwan 2008, 5, 34-43.

42. Zielony, R. Zgodność fitocenozy z biotopem w ekosystemach leśnych. In Praca Zbiorowa; Zielony, R., Ed.; Fundacja Rozwój SGGW: Warszawa, Poland, 2001; p. 231. 
43. Instrukcja Urządzania Lasu. Państwowe Gospodarstwo Leśne Lasy Państwowe Część 1 Instrukcja sporządzania planu urządzenia lasu dla nadleśnictwa Załącznik do Zarządzenia nr 55 Dyrektora Generalnego Lasów Państwowych z dnia 21 listopada 2011, Warszawa.

44. Brzeziecki, B. Wskaźniki zróżnicowania struktury drzewostanu. Sylwan 2002, 4, 69-79.

45. Zasady Hodowli Lasu. Obowiązujące w Państwowym Gospodarstwie Leśnym Lasy Państwowe. Wprowadzone w życie na mocy art. 33 ustawy z dnia 28 września 1991 r. o lasach (tekst jednolity ze zmianami Dz.U. Nr 56, poz. 679 z 2000 r.) zarządzeniem Nr 53 Dyrektora Generalnego Lasów Państwowych z dnia 21 November 2011, Warszawa.

46. Bellon, S.; Bernadzki, E.; Żybura, H. Przebudowa drzewostanów: rodzaje, kryteria, pilność. Zeszyty Postępu Techniki w Leśnictwie 1997, 61, 5-10.

47. Strategia 2013. Strategia Państwowego Gospodarstwa Leśnego LP na lata 2014-2030.

48. Balteiro, L.D.; Romero, C. Making forestry decisions with multiple criteria: A review and an assessment. For. Ecol. Manag. 2008, 255, 3222-3241. [CrossRef]

49. Borecki, T.; Stępień, E.; Wójcik, R.; Orzechowski, M. Verification of the principles of accounting for the size of the allowable fellings in the forest management planning. Drewno 2016, 59, 61-75. [CrossRef]

50. Stępień, E. Idea trwałości lasu (nowe treści, problem realizacji). Sylwan 1995, 12, 5-11.

51. Rykowski, K. Kryteria i indykatory trwałego i zrównoważonego zagospodarowania lasów. In Problemy Realizacji Proekologicznego Modelu Leśnictwa Metodami Aktywnej Gospodarki Leśnej; Rykowski, K., Ed.; Wyd. SGGW: Warszawa, Poland, 1995; pp. 205-220.

52. Głaz, J. Kryteria i wskaźniki trwałej i zrównoważonej gospodarki leśnej w planowaniu urządzeniowym. Biblioteczka Leśniczego 2003, 184, 1-18.

53. Vacik, H.; Wolfslehner, B. Entwicklung eines Indikatorenkatalogs zur Evaluierung einer nachhaltiger Waldbewirtschatung auf betrieblicher Ebene. Scheiz. Z. For. 2004, 155, 476-486. [CrossRef]

54. Borecki, T.; Brzeziecki, B.; Stępień, E.; Wójcik, R. Development of forest inventory methods in multifunctional forest management. Folia For. Pol. Ser. A For. 2015, 57, 120-125. [CrossRef]

55. Mäkelä, A.; del Río, M.; Hynynen, J.; Hawkins, M.J.; Reyer, C.; Soares, P.; van Oijen, M.; Tomé, M. Using stand-scale forest models for estimating indicators of sustainable forest management. For. Ecol. Manag. 2012, 285, 164-178. [CrossRef]

56. Schmid-Haas, P.; Baumann, E.; Holdenrieder, O.; Keller, W.; Ramp, B.; Stępień, E. Infektionen der Stuetzwurzeln, Kronenverlichtung und Zuwachs bei Fichten und Tannen. Mitt. Eidgenoss. Forsch. Anst. Wald Schnee Landsch. 1997, 72, 131-244.

57. Stępień, E.; Gadola, C.; Lenz, E.; Schaer, E.; Schmid-Haas, P. Die Taxierung der Holzqualitaet am stehenden Baum. Ber. Eidgenoss. Forsch. Anst. Wald Schnee Landsch. 1998, 344, 1-68.

58. Stępień, E. Znaczenie informacji w urządzaniu lasu na tle aktualnych zadań leśnictwa. Sylwan 1996, 1, 45-51.

59. Zeng, H.; Talkkari, A.; Peltola, H.; Kellomäki, S. A GIS-based decision support system for risk assessment of wind damage in forest management. Environ. Model. Softw. 2007, 22, 1240-1249. [CrossRef]

60. Shao, G.; Wang, H.; Dai, L.; Wu, G.; Li, Y.; Lang, R.; Song, B. Integrating stand and landscape decisions for multi-purposes of forest harvesting. For. Ecol. Manag. 2005, 207, 233-243. [CrossRef]

61. Shao, G.; Dai, L.; Li, Y.; Liu, Y.; Bai, G. FORESTAR: A decision support system for multi-objective forest management in Northeast China. J. For. Res. 2003, 14, 141-145.

62. Costa Freitas, M.B.; Xavier, A.; Fragoso, R. An integrated decision support system for the Mediterranean forests. Land Use Policy 2017. [CrossRef]

63. Eggers, J.; Lindhagen, A.; Lind, T.; Lämås, T.; Öhman, K. Balancing landscape-level forest management between recreation and wood production. Urban For. Urban Green. 2018, 33, 1-11. [CrossRef]

64. Olaczek, R. Olaczek, R. O niespójności w systemie ochrony przyrody w Polsce. In Ochrona Przyrody w Polsce Wobec Wspótczesnych Wyzwań Cywilizacyjnych; Mirek, Z., Nikiel, A., Eds.; Komitet Ochrony Przyrody PAN: Kraków, Poland, 2014; pp. 239-255.

65. Stępień, E. Premisses in forest management for development of resistivity of stands to some abiotic factors. In Proceedings of the 3rd Symposium on the Protection of Forest Ecosystems, Rogów, Poland, 20-21 November 1984.

66. Wolfslehner, B.; Vacik, H. Evaluating sustainable forest management strategies with the analytic network process in a pressure-state-response framework. J. Environ. Manag. 2008, 88, 1-10. [CrossRef] [PubMed] 
67. BMUJF. Testung von Kriterien und Indikatoren einer nachhaltigen Waldbewirtschaftung in Oesterreich im Rahmen eines internationalen CIFOR Projektes; Bundesministerium fuer Umwelt; Jugend und Familie: Wien, Austria, 1996.

68. BUWAL. Praxishilfe-Kontrolle der Nachhaltigkeit im Wald; Bundesamt fuer Umwelt; Wald und Landschaft: Bern, Switzerland, 2003.

69. NFV. Indikatoren nachhaltiger Forstwirtschaft. Bericht ueber das deutsche Teilprojekt; Schrieftenreihe Waldentwicklung in Niedersachsen; Niedersaechsische Forstl. Versuchsanstalt: Wolfenbuettel, Germany, 2003.

70. Borecki, T.; Orzechowski, M.; Stępień, E.; Wójcik, R. Przewidywane oddziaływanie zmian klimatu na ekosystemy leśne i możliwe środki zaradcze. Sylwan 2017, 161, 531-538.

71. Kundzewicz, Z.W.; Radziejewski, M.; Pińskwar, I. Precipitation extremes in the changing climate of Europe. Clim. Res. 2006, 31, 51-58. [CrossRef]

72. Brzeziecki, B.; Keczyński, A.; Zajączkowski, J.; Drozdowski, S.; Gawron, L.; Buraczyk, W.; Bielak, K.; Szeligowski, H.; Dzwonkowski, M. Zagrożone gatunki drzew Białowieskiego Parku Narodowego (Rezerwat Ścisły). Sylwan 2012, 4, 252-261.

73. Drozdowski, S.; Brzeziecki, B.; Żybura, H.; Żybura, B.; Gawron, L.; Buraczyk, W.; Zajączkowski, J.; Bolibok, L.; Szeligowski, H.; Bielak, K.; et al. Wieloletnia dynamika starodrzewów w zagospodarowanej części Puszczy Białowieskiej: Gatunki ekspansywne i ustępujace. Sylwan 2012, 156, 663-671.

74. Hanewinkel, M.; Cullmann, D.A.; Schelhaas, M.-J.; Nabuurs, G.-J.; Zimmermann, N.E. Climate change may cause severe loss in the economic value of European forest land. Nat. Clim. Chang. 2013, 3, $203-207$. [CrossRef]

75. Kowalski, M. Changes in forest species composition as related to climate change during the last two centuries. In Proceedings of the Vth Symposium on the Protection of Forest Ecosystems. Forest Biodiversity Protection Program GEF 05/21685 POL20-21, Białowieża, Poland, 18-20 October 1993; pp. 23-35.

76. Ray, D.; Petr, M.; Mullet, M.; Bathgate, S.; Marchi, M.; Beauchamp, K. A simulation-based approach to assess forest policy options under biotic and abiotic climate change impacts: A case study on Scotland's National Forest Estate. Fort Policy Econ. 2017. [CrossRef]

77. Kraeuchi, N. Potential impacts of a climate change on forest ecosystems. Eur. J. For. Path. 1993, 23, 28-50. [CrossRef]

78. Brzeziecki, B. Skale nominalne wymagań klimatycznych gatunków drzew leśnych. Sylwan 1995, 3, 53-65.

79. D'Amato, A.W.; Bradford, J.; Fraver, S.; Palik, B. Forest management for mitigation and adaptation to climate change; Insights from long-term silviculture experiments. For. Ecol. Manag. 2011, 262, 803-816. [CrossRef]

80. Rykowski, K. Program Działań Dla Adaptacji do Zmian Klimatu w Poszczególnych Sektorach Gospodarczych; Sadowski, M., Ed.; Klimada-Instytut Ochrony Środowiska: Warszawa, Poland, 2012.

81. Zajączkowski, J.; Brzeziecki, B.; Perzanowski, K.; Kozak, I. Wpływ potencjalnych zmian klimatycznych na zdolność konkurencyjną głównych gatunków drzew w Polsce. Sylwan 2013, 157, 253-261.

82. Knoke, T.; Hahn, A. Baumartenvielfalt und Produktionsrisiken: Ein Forschungseinblick und-Ausblick. Schweiz. Z. Forstwes. 2007, 158, 312-322. [CrossRef]

83. Rauscher, H.M. Ecosytem management decision support for federal forests in the United States: A review. For. Ecol. Manag. 1999, 114, 173-197. [CrossRef]

84. Plochmann, R. Der Forstmann vor der Herausforderung durch die wissenschaftlich-technische Welt. Der Deutsche Forstmann. 1982, 22, 231-232, 257-259.

85. Oesten, G. Anmerkungen zur Nachhaltigkeit als Leitbild fuer naturvertraegliches Wirtschaften. For. Cbl. 1993, 112, 313-319. [CrossRef]

86. Glueck, P. Von der oekonomischen zur oekologischen Nachhaltigkeit. Oesterr. For. 1994, 8, $24-28$.

(C) 2018 by the authors. Licensee MDPI, Basel, Switzerland. This article is an open access article distributed under the terms and conditions of the Creative Commons Attribution (CC BY) license (http:/ / creativecommons.org/licenses/by/4.0/). 